Comparative Philosophy Volume 6, No. 1 (2015): 38-55

Open Access / ISSN 2151-6014

www.comparativephilosophy.org

\title{
HAZEL BARNES AND OCTAVIO PAZ: TWO EXISTENTIALIST AND PAN-AMERICAN PHILOSOPHIES OF EDUCATION
}

\author{
JOHN KAISER ORTIZ
}

\begin{abstract}
As loyal critics of the university whose worldviews furthered key existentialist commitments, Octavio Paz and Hazel Barnes advanced philosophies of education inspired by the struggles of the 1968 student social protest movements. Their appeals to what a complete university education is and ought be demonstrate remarkable compatibility given their existentialist affinities and so are relevant to a normative critique of the mission of today's colleges and universities. Both took seriously the idea that the university's didactic mission should include the ideal of cultivating a socially and politically desirable, and morally defensible, account of the individual self in action. These thinkers also contended that the university should be seen as a place where selves in action rehearse engaged moral reflection towards self-fulfillment and social justice across generations. Seen against the violence that marred such episodes as the police riots during the Democratic Convention in Chicago in August 1968 and the Tlatelolco Massacre in Mexico City weeks later, my argument demonstrates how and why the radical normative underpinning of Barnes' and Paz's philosophies of education offer important guidelines for appraising the purposive nature of today's university. One key outcome of my paper is that it points the way towards what I will call a pan-American existentialist philosophy of education that is responsive to the generational needs, ideals, and challenges of students today across the universities, communities, and nations of the western hemisphere, especially between the United States and Mexico.
\end{abstract}

Keywords: Existentialism, Hazel Barnes, Octavio Paz, Tlatelolco Massacre, student activism

As loyal critics of the university whose worldviews furthered key existentialist commitments, Octavio Paz and Hazel Barnes put forward philosophies of education that were inspired by the struggles and idealizations of the 1968 student and social protest movements. Attuned to the revolts of Blacks and Chicanos in the United States, their appeals to what a genuine and complete university education is and ought be demonstrate remarkable compatibility given their shared existentialist affinities

KAISER ORTIZ, JOHN: Assistant Professor of Philosophy, Millersville University, USA. Email: john.kaiserortiz@millersville.edu 
and are thus eminently relevant to a normative critique of the mission of today's colleges and universities. The national contexts and cultural settings from which these thinkers wrote were, of course, different-Barnes was writing in the United States, Paz in Mexico. Yet, both took seriously the idea that the university's didactic mission should include the ideal of cultivating a socially and politically desirable, and morally defensible, account of the individual self in action. In seeking to concretize relations between values and the excogitative space required for thinking them through as a foundation for moral and political criticism, these thinkers contended that the university should be seen as a place where selves in action rehearse engaged moral reflection towards self-fulfillment and social justice across generations.

My argument in this essay demonstrates how and why the radical normative underpinning of Barnes' and Paz's philosophies of education offer important guidelines for appraising the purposive nature of today's university. Three particular claims unite these two perspectives; I refer to them as the threefold structure (or pyramid) of their affinity. First, their accounts of what an existentialist philosophy of education might look like are framed in terms of the normative proposition that any meaningful diagnosis of the conditions suffered by today's university and its members should be centered on the question of values. Second, both believed that the rehearsal or practice of values at the university provides the necessary experience of circumstances needed for maintaining robust deliberative democratic practice. Third, their manner of linking values to lived experience as the bedrock for moral criticism is relevant to the life projects and community relations of all human beings - across borders, throughout the hemisphere, and around the world. Hence these guidelines give direction to selves in action (i.e., social actors or moral agents) for developing criticism from within multidimensional, ever-changing, and transnational contexts. These guidelines also offer a public and philosophical measure for assessing how far a society has gone in terms of articulating, engaging, and realizing its professed values and ideals.

Seen against the violence that marred such episodes as the police riots during the Democratic Convention in Chicago in August 1968 and the Tlatelolco Massacre in Mexico City weeks later, the existentialist philosophies of education proposed by Barnes and Paz offer models that are helpful towards assessing the extremes of student activism on campuses today. Indeed, among the most pressing issues facing teachers, students, and activists today is where to nurture a collective loyalty to those values and actors affected by and operating not just within institutions of higher education, but also throughout the body politic and society at large. Consequently, given that the broad contours of these critical methodologies are framed by an evaluation of the meaning of a university education, the mission of the university, and a defense of student protest, one key outcome of my paper is that it points the way towards what I will call a pan-American existentialist philosophy of education that is responsive to the generational needs, ideals, and challenges of students today across the social differences and national borders of the peoples and countries of the Americas, i.e., across the universities, communities, and nations of the western hemisphere, especially between the United States and Mexico. 
Three consequences follow from the existentialist philosophies of education I will examine in this essay. The first is that the significance of a university education should be based on exposing students to the importance of moral values in general and to the value of criticism in particular. This moral criticism is of personal, social, and political significance. Practice in the art or skill of moral criticism should be the centerpiece of any university's mission, especially given the pledge of a liberal arts education to individual student growth. The second outcome is based on the observation that both figures saw the university as a place where social, political and moral criticism (including personal or self-criticism) gets practiced, played out, and rehearsed. This distinction between criticism of one's own personal self and criticism of sociopolitical institutions and others sets the university apart as a place where values are, in a sense, practiced or played out (exercised, stretched, conditioned), thereby making institutions of higher education unlike any other in the contemporary world. However, the third outcome is predicated on the first two consequences and provides a key contrast between their outlooks. The most critical difference between the accounts of Barnes and Paz on these matters can be summarized by stating that while both viewed the university as a community as well as a uniquely creative place where students gain exposure to different modes or forms of criticism, they disagreed about what was perhaps the most important or distinctive feature of a university education. Paz will focus on what he calls the paradox of distance in order to emphasize that criticism in any form is dependent upon students being able to see their own relationship to society as the condition of their thought. Barnes, on the other hand, will view this basic groundwork of criticism (of self criticism as much as moral criticism) as the basis for claiming that what this exposure to criticism at the university level ultimately provides students is the basic framework for developing what she calls an art of living.

Together, these two glosses constitute what I am calling the twin directions of moral criticism (personal and sociopolitical), both of which are only possible because, in the university Barnes called the privilege of sanctuary, and at the college of Paz, "the university is at once the object and the condition of student criticism" (Paz 1985, 223). Barnes' indirectly alludes to one way in which thinking through an art of living requires understanding the relation of distance between the university and society: "classroom discussions of social theories and of the moral dilemmas of literary heroes and heroines were fore-runners of the teach-ins on Vietnam and Civil Rights...questions of ethical responsibility have not been strangers in classes and humanities and the social sciences" (Barnes 1970, 26-27). The distance between the university and the community at large is the necessary space from which criticism in any form becomes possible. Thus, like an art of living, the paradox of distance emerges in the creative and deliberative space between the life of university students and the society at large from which their lives as university students are removed; in this space also emerges a viable philosophy of life. Both the paradox of distance and the art of living therefore call attention to Barnes' and Paz's social, political, and moral defense of the student protests of 1968 and so tightens the existentialist and pan-American tether of their philosophies of education. 
The pan-American existentialist philosophy of education I will gesture towards in this essay aims to contribute to the growing body of literature on Latin American philosophy, adding in particular a study of the existentialist underpinnings of North American and Latin American engagements of social protest movements, the foundations of moral criticism, and the social and political value and significance of a university education. This perspective occasions the claim that perhaps future relations between the peoples and countries of the western hemisphere might come to be seen as related in a way that emphasizes the place of individuals in society and the need for each new generation to critically engage the social, political, and moral realities of their communities in order to make them more their own. My conclusion suggests that a pan-American existentialist philosophy of education provides a foundation for building bridges of solidarity across the borders and boundaries of life as it is lived, known, and studied across the Americas.

\section{REBEL BEATNIKS AND STUDENT ACTIVISTS: BARNES ON EDUCATION IN THE ART OF LIVING}

In 1950, Hazel Estelle Barnes taught the first course offered in North America on Existentialism at the University of Toledo (Cannon 2008, 92). In an editorial written for that university's student newspaper the Collegian (found in the University of Toledo Archives) in March that same year, Barnes lamented that the American educational system reinforced the disturbing cultural practice whereby citizens "undersell" themselves and students have "far more desire to be laughed at as stupid than damned as a serious student" (Barnes 1950, 1). Barnes would revisit these themes of American anti-intellectualism, obscurantism, and deteriorating educational standards time and again throughout her distinguished academic career. Her obvious disappointment would echo in a book chapter entitled "Existentialism and Education," written seventeen years later, where she claims that "there is a great paradox in American education" and, in her opinion, "it would be fair to say that most American children receive absolutely nothing of what can in any significant sense be called education in ethics" (Barnes 1967, 292). In her autobiography published in 1997, she doubts "that it is possible to teach anything, even basic science or a skill, without transmitting something of one's own values" (Barnes 1997, 219). Unsurprisingly, Barnes' passion for education characterizes how she is remembered by her closest friends, who recall Barnes as taking seriously the responsibility for "putting into practice her avowed intentions and values" (Cannon 2008, 96).

Barnes' personal values were apparently indistinguishable from the sociopolitical standards and ideals of human conduct she hoped to impart to her students through her teaching and, through her publications, to the philosophical community at large. Prior to becoming known as the translator of Sartre's Being and Nothingness (originally published in France in 1943, first English translation published in 1956; See Anne Sophie-Cohen 1989, 188; Barnes 1997, 150), Barnes' burgeoning scholarship delved into Sartre's account of the living, concrete individual, especially the paradoxes he thought shaped the lived experience of existing human beings (See 
Barnes 1956, "Jean-Paul Sartre and the Haunted Self"). Barnes' early work also examined questions of self-realization in the work of Albert Camus, whose work she interpreted along Aristotelian lines (See, for example, Barnes 1960, "Balance and Tension in the Philosophy of Camus").

In The University as the New Church (1970), Barnes outlines a normative existentialist critique of "the University as it is and as it might be" (Barnes 1970, vii). Comparing the university of today with the church of yesterday, Barnes observes that "the similarity of the situations in which University and Church now find themselves suggests that in their fundamental nature there must be some common likeness" (Barnes 1970, 2). Barnes then claims that questions of self-knowledge, personal identity, and seriousness (i.e., maturity, or the ability to face difficult challenges or recognize the gravity of situations, etc.), in addition to the acquired ability to critically evaluate one's moral standing, comprise the core ethical values, principles, and ideals imparted by a university education, including religious universities. This orientation leads her to assert that the university (not unlike the church) seeks to accomplish three distinct goals: "to point out the path to truth, to instruct the young, to guide man toward the good life" (Barnes 1970, 2). Seen along these lines, the existentialist dimensions of Barnes' critique of the university (and the church) frame her sense of the importance of developing one's personal and sociopolitical priorities and rules of conduct towards what she broadly construes as moral criticism. As such, Barnes work addresses the relationship between what she calls "our basic way of life" and the values that underwrite personal and well as sociopolitical criticism (moral criticism) across generational difference.

Among the most fundamental lessons Barnes believes any meaningful university education teaches stems from her insight, I think, that values are in a theatrical as much as a moral sense rehearsed (produced, staged, performed, deconstructed, etc.) at the university. To rehearse values means to test principles, viewpoints, and consequences through the exchange and sometimes conflict of ideals that lies at the heart of ethical and deliberative discourse. At the university, values are not just examined but also practiced or played-out (exercised, stretched, conditioned) in a setting where participant members contribute thoughtfully and genuinely (one also hopes sincerely) to the pressing issues of the contemporary world through critical engagement with the examples, ideas, and experiences under consideration-under production, as it were. Through the staging and rehearsal of scenarios based on the dialogues of fictional and non-fictional narratives, then, a university education produces momentous ideas about the world of human experience, and these ideas, once rehearsed, bracket the core values that shape our thinking about the world and so help us to determine how we might act. (Philosophy in particular produces ideas about ideas. We might call this production of ideas about ideas the supreme value of the university mission - to study, produce, and evaluate ideas that inform our lived experience.) Rehearsing values thus means exchanging ideas and reaching conclusions about how one should live her life and what one should ultimately care about in life. Rehearsing values also means having a tentative sense of direction mapped out (staged) for the imminent performance. None of this suggests that one 
forgets that the map might have to be improvised and redrawn at a moment's notice should the staging or rehearsed plan of action fall apart. The suggestion does arise however that the traditional view of the value of a liberal arts education as being predicated upon the claim of knowledge for its own sake might need to be downgraded to focus on the practical philosophy required for living a meaningful and fulfilling existence.

Not everyone is cut out for acting, of course. Similarly, not everyone benefits from nor is meant for a liberal arts education. This is only to say that students fortunate enough to attend the university enjoy a moral opportunity not universally shared by the larger portion of society's members. Barnes doubtless anticipated this singular privilege, for she frames this mark of differentiability in terms that restate the importance of rehearsing values at the university as a generational practice towards engaging personal and sociopolitical realities faced later in life. She observes, "For the most part in contemporary culture there is no built-in plan whereby no person may come of age without having been exposed to thoughtful discussions of personal value systems and social responsibilities" (Barnes 1970, 13). This quote provides a key instance where Barnes' claims about the importance of moral criticism underscores her purported sense of the mission of the university. Barnes' focus is not on isolated conclusions one reaches in college (like the question about whether or not to support war; to accept the belief in God, or if polyamory is more desirable than marriage, and so on). Instead, her focus is on the structure of relations between individuals and the society into which they enter as educated and experienced moral agents facing a world of mixed, multifarious, and unpredictable conflict. This quote also demonstrates the assumed importance that an open future plays in terms of framing Barnes' discussion of "personal value systems and social responsibilities," or what I have been calling the personal, social, and political consequences of moral criticism.

Granted that the working out or practice of values at the university is an opportunity we might all benefit from (Barnes seems to think that everyone should benefit from such practice), relatively few members of society ever get a chance to rehearse (without consequence or the threat of punishment) their personal and sociopolitical commitments. This reality further distances the unique moral worldviews students seen as social actors/moral agents acquire through a university education that sets them apart from the rest of a given community's members. (United States Census data indicates that roughly 1 in 4 Americans has a baccalaureate college degree.) The peculiar advantage of being a college student is not free from its own limitations. The problem Barnes sees with the university in the late 1960s is that "under the guise of detachment and non-commitment, the University has been handling the problems of values surreptitiously and performing its religious duties badly. It has become a Church without ever clearly formulating its faith or seriously examining the worth of its plan for salvation" (Barnes 1970, 19). The language of formulating a faith rests within the domain of ethics, while "seriously examining the worth of its plan" underscores the importance of education.

What begins to appear at this point is an outline, on the one hand, of Barnes' broader concern with what an existentialist philosophy of education might look like, 
with the weightier question of what an existentialist ethics might look like, on the other. Hanging in the balance between both views is the issue whether and how a university education teaches us how to think and act, and how a university education therefore relates to the tenets of both moral purviews. Barnes is unambiguously clear about the underlying value of the relationship between ethics and education: "the underlying faith of the University in its own mission should rest simply on the conviction that all men and women are worth saving" (Barnes 1970, 191). Clearly, a concern with individual redemption furnishes one of the primary goals Barnes believes should be the focus of a university's mission. From the relationship between ethics and education then emerges the topmost personal value and engaged social ideal of an open future, or the idea that the individual selves in action who represent each new generation can determine for themselves and on their own terms which primary values (and commitments) should govern their deliberations and decisionmaking as mature and responsible social actors/moral agents. Consequently, Barnes, like Paz, holds a critical view of the reality of higher education in the sense that those drafted to fight (and die fighting) the war in Viet Nam were not even granted an audition for this theater of possibility and so will not get a chance to be actors on the stage of world history.

Barnes' philosophy of education, whatever its historical, present, and ongoing dilemmas, is based on the belief that the university is and should be a safe place or neutral ground, a kind of moral rehearsal studio where the burgeoning leaders and inchoate visionaries of the next generation can work out their ideas among similarly responsible and committed individuals. This is why she claims that "whatever we may think of what student protestors propose for the future, they are right in thinking that in the University rests the best, perhaps the only, hope of initiating significant changes in the life of man" (Barnes 1970, 19). But where would such a project begin, and towards what end would these changes be directed? Barnes' hope for the positive transformative role a university can play towards achieving virtuous and just realities is optimistic. After all, the question of evaluating the true mission of the university involves asking how might we go about initiating significant changes in the life of individual selves in action across generations. Unfortunately, however, Barnes is not as forthcoming in her response to such questions as we might expect. Nevertheless, one answer we might venture to give to such an important question could involve demonstrating that this transformative project is strengthened and concretized at the level of higher education. One might further claim in response that an education suitably focused on values will eventually lead to a more robust sense of the vital importance of moral criticism for social actors/moral agents who value personal and sociopolitical flourishing, i.e, a healthy deliberative democracy. Both of these potential responses are, in any case, suggested by the conjoining of existentialist principles with a philosophy of education. As a bridge between her existentialist ethics and her philosophy of education, it is telling that Barnes wrote The University as the New Church (1970) three years after developing her rendering of a Sartrean ethics in An Existentialist Ethics (1967). 
Barnes repeatedly sought to demonstrate in her own writings what an existentialist ethics might look like, practically and theoretically. Barnes' account of the moral life was distinguished from but still partly based on what she thought Sartre's ethics might entail. Sartre, we remember, had promised but never delivered his work on ethics. Nevertheless, Barnes claims that "ethical concerns are implied in all of his works" (Barnes 1997, 147). She credits Sartre with having "developed the idea (or, if 'developed' is too strong a word, he suggested it) that if we want to live authentically - i.e., consistently with the truth of our human condition-we must individually create our own ethics, that since we are responsible for the selves we have made and are making, we must answer for them, at least to ourselves" (Barnes 1997, 147). Barnes ultimately viewed her own attempt at formulating an existentialist ethics "a feeble effort...that glaringly demonstrates the gap between intention and achievement" (Barnes 1997, 147). And yet, although Barnes may have viewed her own interpretation of an existentialist ethics with suspicion, it was clear to her that "implicit in [Sartre's] declaration that in choosing for ourselves, we choose for humankind, I heard the plea for the need to develop collectively an ethics appropriate to all of humanity that would not violate individuals' freedom to establish their own value systems" (Barnes 1997, 147). Barnes would never doubt that an existentialist philosophy of education could help foster a meaningful system of personal values that compel one to negotiate the larger communities to which one belongs, even if such an education might fall short of developing a complete or systematic ethics for every student passing through the hallowed halls of academe.

In spite of these limitations, An Existentialist Ethics (1967) deserves more credit than Barnes gives it. Readers familiar with this work will recall that the view of ethics (the moral framework) she develops in this work begins from a cultural and psychological portrait of social rebels in American society: beatnik poets, social organizers, political activists, new radicals, and Norman Mailer. By positing as central to any understanding of the human condition two fundamental, yet opposite extremes of lived experience as chronic boredom versus intense living, Barnes defends her belief that existentialism is uniquely positioned to respond to the humanistic desires and moral demands of the coming-of-age generation of the middle twentieth century.

The teacher should try to teach what we may unabashedly call the art of living; like any instructor in the arts, he or she must have practiced that art personally and be able to communicate the fruits of experience while remembering that the aim is to enable the child to develop his own talents and not merely to imitate (Barnes 1970,182).

The art of living becomes, then, the enduring priority of what I have been calling moral criticism, both in its personal and sociopolitical manifestations. Barnes' outlook echoes the philosophy of education voiced by William James, under whose influence Barnes claims she was raised. In Talks to Teachers on Psychology (1899), James described the ideal of education as "the organization of acquired habits of conduct and tendencies to behavior" (James 1958, 37). Barnes, speaking directly to 
the influence of the 1960s student and social protest movements on her thinking about ethics and education, and as evidence of James' influence on Barnes' thinking about the art of living, remarks "that our basic way of life will have to be radically modified in the face of the ecological crisis" (Barnes 1967, vix). Doubtless this crisis has worsened in the nearly half-century since these two works were published. Barnes proposes that an existentialist philosophy of education that values responsibility, moral criticism, and an open future are spelled out and so can collectively stand for "a humanistic existentialist ethics [that] is peculiarly well suited to deal with the conflicting demands of a society in transition" (Barnes 1967, vix).

The supreme value Barnes idealizes through her existentialist philosophy of education is love. Through love, Barnes' is able to emphasize the transformative social role educated individuals might have on the society into which they enter after graduation. As Barnes describes it, "love is the value offered as the bridge between the individual and society or, if your prefer, as the cement which can hold people so closely together that whatever is conceived as good for the whole will automatically include the legitimate needs of the individual" (Barnes 1970, 161). Love for Barnes is

a moral antidote to prevailing forms of oppression, e.g. elitism and inequality in their endless mutations, which explains why she claims that, "by stressing the ideals of service and self-fulfilment (sic) rather than social approval and material success, we may gradually rub out the scars of centuries of elitism" (Barnes 1970, 179). Seen in this way, Barnes' existentialist philosophy of education shows itself as moral criticism, e.g., as an art of living, that may also take equality as a serious personal and sociopolitical priority or commitment. As evidence of this claim, Barnes points out that "love reminds us that reverence for the need of every individual is the sole support of human solidarity" (Barnes 1970, 190). Consequently, the practices valorized by a university education come to reflect the values of individual selves in action; likewise, the rehearsal of values like love becomes the foundation for a healthy, thriving body politic.

As I will show in the next section, Barnes' focus on values and her elevation of the human search for meaning in "the privilege of sanctuary" (Barnes 1970, 3) can be seen as related to Paz's critique of the university's peculiar mission and its instrumental role in fostering and maintaining democratic vitality, e.g., the exchange of viewpoints and ideas necessary for living in a peaceful society. Barnes' critique provides an illustration of the kind of criticism Paz proposes, one couched in terms of a clearly normative evaluation of the purpose or mission of a university. By the same token, Paz adds to Barnes' existentialist philosophy of education a more rigorously articulated account of and politically deeper engagement with moral criticism and its centrality in the university.

\section{PAZ ON MORAL CRITICISM AND THE VIOLENCE AGAINST STUDENT PROTEST}

The philosophic thought of Octavio Paz is imbued with existentialism of the post-war Parisian years, during a period Paz calls the "high noon of [Sartre's] glory and 
influence" (Paz 1992, 36). One could argue (as I have elsewhere; see Kaiser Ortiz 2012) that Paz's thought not only epitomizes existentialism in Mexico but also moves critically beyond the accounts of solitude, love, and freedom developed by his contemporaries, including Simone de Beauvoir and Jean-Paul Sartre, whom Paz met (and later wrote on) while living in Paris between 1948-1950 working for the Mexican foreign service. Perhaps the most concrete evidence of Paz's abiding commitment to feminist criticism alongside his articulations and expressions of existentialist philosophical concerns like the problem of solitude is to be found in his wholesale adoption of Beauvoirs' account of women as being not born but rather becoming themselves-particularly in Mexico, as is his adopted viewpoint throughout The Labyrinth of Solitude. Indeed, Paz's most famous essay The Labyrinth of Solitude was written while he was living in Paris immediately after the second world war. What can be called Paz's critique of modernity is in many ways a pan-American critique of North American and European existentialism.

The Other Mexico (1970) is a three-part essay based on the Hackett Memorial lectures Paz gave at the University of Texas at Austin on 30 October 1969. This essay was written as a denunciation of the Mexican government's blood-spilling orgy in Mexico City's Plaza de Tres Culturas, an episode more commonly known as the Tlatelolco Massacre when hundreds of protesting students were executed en masse by members of the Batallón Olimpia, an elite division of the Mexican military-just ten days before the start of the Olympics in Mexico City, the first time the prestigious sports event was sponsored in a developing nation. Paz was so deeply moved by these student demonstrations that he joined them. After the slaughter on 2 October 1968, Paz resigned his diplomatic post as Mexico's ambassador to India. Enrique Krauze would later call this act "his finest hour, an unheard-of gesture in Mexico" that "founded a culture of intellectual dissidence in Mexico" and throughout Latin America (Krauze 1998). In this essay, written one year later, Paz distances himself from questions of national identity he had explored earlier in The Labyrinth of Solitude (1950), focusing now on the socio-political necessity of moral criticism for attaining democratic institutions and practices.

The two features of Paz's philosophy of education I develop in this section focus on his remarks on the social-political distance of the university and the requirement of moral criticism for furthering, advancing, and ensuring democratic development. Paz enlarges the account of moral criticism Barnes offers (personal criticism of oneself and social-political criticism of institutions and others) to focus not simply on cultivating the art of living (although Paz clearly thinks this is one part of a meaningful education), but on developing democratic institutions and practices. Paz thus defends the criticism that the Mexican studentry embodies and the university as an institution represents. In the context of Tlatelolco, the Mexican government's publicly grotesque, murderous aggression against its own citizens dramatizes Paz's insight into the social and political relevance, and moral purpose, of a university education. The fact that these Mexican students were murdered by their own government adds urgency to Paz's ideas on education that is not as pronounced in Barnes, even though her Preface to The University as the New Church was written in 
May 1970, the same month in which the Kent State University Massacre (4 May 1970) took place, killing four students and wounding nine in Ohio.

For Paz, the university constitutes an immersive theater of discourse shaped by its physical removal and psychological distance from the social and political realities to which the university community is connected. This distance is necessary, Paz thinks, in order to foster critical thinking about the same society from which student life is separated. In "Olympics and Tlatelolco," the first of three sections that comprise The Other Mexico, Paz discusses how "of all the disaffected sectors, that of the students is the most restless and, with the exception of the North American blacks, the most exasperated" (Paz 1985, 222). The reason for this edginess and impatience is that

their exasperation does not spring from particularly hard living conditions but from the paradox that being a student entails: during the long years in which young men and women are isolated in schools of higher education, they live under artificial conditions, half as privileged recluses, half as dangerous irresponsibles (Paz 1985, 222).

Paz's claim about artificial conditions mirrors Barnes' general outlook, as when she writes, "the University has attempted to prolong the adolescence of students, in effect asking them to study now and live later" (Barnes 1985, 27). This notion of postponing instruction in the art of living means that the paradox of distance becomes a hindrance for the artful living Barnes proposed. Paz's account of moral criticism relates to his regard for the university not in terms of any mission per se, but rather on the physical separation and de facto segregation of students from the society to which their criticism is directed.

Paz's clearest statement of a philosophy of education emerges from his sense of how criticism materializes and becomes real for university students. "The university is at once the object and the condition of student criticism" (Paz 1985, 223). Paz substantiates his characterization of criticism in a manner that bears out quintessential existentialist motifs.

It is the object of their criticism because it is an institution that segregates the young from the collective life and is thus, in a way, an anticipation of their future alienation. They discover that men are fragmented and separated by modern society: the system, by its very nature, cannot create a true community. And it is the condition of the criticism because, without the distance that the university establishes between the young and the society outside, their criticism would not be possible and the students would immediately enter into the mechanical cycle of production and consumption. The contradiction is irresolvable (Paz 1985, 223).

While Paz might here appear (misleadingly, I think) to have a fatalistic attitude about the moral significance of a university education, it is apparent that Paz sees university students not just in Mexico but also around the world in 1968 as members of an emergent collective, universal human identity. Paz denounces the carnage of Tlatelolco as an unconscionable assault on the moral potentialities promised by universal human identity, a relationship directly tied to his interest in students of the 
period who saw their national struggles in terms of solidarity with students elsewhere. Significantly, "the universality of youthful protest has not prevented it from assuming specific characteristics in each region of the world" (Paz 1985, 227). Paz's caveat in his epigraphic "note" reiterates his concern not just with Mexican-ness (Mexicanidad), but also with universal human identity. In his words, "Mexican-ness is no more than another example, another variety, of that changing, identical, single, plural creature that each is, all are, none is. Man/men: perpetual oscillation. The diversity of characters, temperaments, histories, civilizations makes of man, men. And the plural is resolved, is dissolved, in the singular: I, you, he, vanishing as soon as pronounced" (Paz 1985, 216). In these passages, Paz can be seen to relate the value of a university education to the collective generational emergence of universal human identity.

Although my focus in The Other Mexico is confined to "Olympics and Tlatelolco," since it is here where Paz locates his discussion of university education and the role of criticism in it, it is worth noting that in the other two sections of his essay, Paz lambasts the idea of progress as it gets experienced differently in North American and Europe, as compared with Mexico and Latin America. Paz is certainly suspicious, if not hostile to the idea of progress. And yet, this criticism serves as the broader backdrop against which his ideas on criticism leading to social, political, and moral development are played out. In the second section of The Other Mexico, for example, "Development and Other Mirages," Paz's stretches the connection between moral criticism and the development of democratic institutions and practices. He writes, "above all and before all else: we must conceive viable models of development, models less inhuman, costly, and senseless than those we have now" (Paz 1985, 283). Interestingly, even though Paz is suspicious of the developmental course Mexican history has taken, especially in the twentieth century, his critique of development as it pertains to North America's political economy strategically targets the big business of war-mongering and war-making. Paz is therefore extremely cautious about the extent to which moral criticism as it is practiced in the United States translates once it has made it across the Mexican border. In Paz's words, "the fusion of the state and what the North Americans call 'the military-industrial complex' is one of the most disquieting aspects of the evolution of the capitalist countries" (Paz 1985, 281). In this way, Paz seems to identify brutal government repression in Mexico as predicated, at the very least influenced by, the desire of developing nations to ape the models of political economy evidenced in the United States and Europe.

In the third section of The Other Mexico, "Critique of the Pyramid," Paz claims that Tlatelolco "was simultaneously a negation of what we have wanted to be since the Revolution and an affirmation of what we have been since the Conquest and even earlier" (Paz 1985, 290). Paz's point is that Mexico and Latin America are faced with radically different social circumstances and limitations than life in more advanced countries. Thus framing Paz's sense of the importance of moral criticism is the question concerning whether and how we can understand our relations to the world, our selves, and others in such a way that "we devise more human models that 
correspond to what we are" (Paz 1985, 217-8). Although the context for Paz's insight here is Mexico's relationship to both Latin America and the United States, the sense of moral criticism that emerges from his essay initially gets expressed as the claim that "the question of ourselves always turns out to be a question of others" (Paz 1985, 218); this claim is soon expanded to signify that "criticism of others begins with criticism of oneself" (Paz 1985, 220).

The Other Mexico engages moral criticism of the structural realities and felt experiences facing Mexicans and, by implication, all human beings in late modernity. Paz's emphasis on the university mission, the values of education, and the moral direction of future generations constitute symbolism. Framed in terms of what he calls modernity's moral failure, Paz asks: "can we plan a society that is not based on the domination of others and that will not end up like the chilling police paradises of the East or with the explosions of disgust and hatred that disrupt the banquet of the West?" (Paz 1985, 218). He goes on to explain that "the question of Mexico is inseparable from that question of Latin America's future, and this, in turn, in included in another: that of the future relations between Latin America and the United States" (Paz 1985, 218).

Paz's pursuit of criticism furnishes the clearest expression of his commitment to existentialist principles, precepts, and practices. "Criticism," he writes, "unfolds the possibility of freedom and is thus an invitation to action" (Paz 1985, 216). Significantly, it is Paz's use of this definition that most clearly demonstrates why he thinks Mexico in addition to Latin American countries need to teach nascent generations of university students the importance and value of criticism for sustaining the development of democratic institutions and practices, including the open and unencumbered exchange of ideas that characterizes healthy, robust deliberative democracies. After all, "the theme of development is intimately linked to that of our identity: who, what, and how we are," writes Paz (Paz 1985, 218).

Like Barnes, criticism of social, political, and moral realities was also Paz's lifelong concern. The Other Mexico is no exception, and "is a reflection upon what has taken place in Mexico since...The Labyrinth of Solitude," twenty years earlier. Referring to this previous work (Labyrinth) as "an exercise of the critical imagination," Paz dubs this newer investigation "a critical and self-critical continuation" (Paz 1985, 215). Although Paz purports an interest in distancing himself from the achievements (and controversies) of Labyrinth, he nonetheless grants their relation to his present essay: "in those days (i.e., when Labyrinth was written) I was not interested in a definition of Mexican-ness but rather, as now, in criticism: that activity which consists not only in knowing ourselves but, just as much or more, in freeing ourselves" (Paz 1985, 216).

To summarize, Barnes' idea that both education in general and the mission of the liberal arts university in particular should teach the art of living resonates with Paz's sense of the importance of moral criticism. The existentialist concern with relations between the self and others is constitutive for both authors of what should be the proper focus of a university education. But in contrast to Barnes' idea that an art of living stands for the value or worth of a liberal arts education, Paz's ideal for 
education appears to be focused on the ability of students in Mexico to criticize and directly challenge the authoritarian control the Partido Revolucionario Institucional (PRI) had over life and thought in Mexico. ${ }^{1}$ Paz's philosophy of education complements Barnes' account in absolute terms: the art of living runs up against unforgiving, if not deadly limits when a government is prepared to kill you for criticism against it.

\section{THIS IS WHAT AN EXISTENTIALIST, PAN-AMERICAN PHILOSOPHY OF EDUCATION LOOKS LIKE}

Barnes and Paz shared a philosophical and pedagogical commitment to a liberal arts education because it provides a worldview selves in action might adopt in order to advance their personal growth and flourishing. Simply put, they take the generational transformation of social, political, and moral realities-including ideas about these realities-seriously. Paz speaks to this point early in The Other Mexico. "If Latin America is living through a period of revolts and transformations," he writes, "the United States is also experiencing an upheaval no less violent and profound: the rebellion of Blacks and Chicanos, of women and the young, of artists and intellectuals" (Paz 1985, 219). In the context of a philosophy of education, Paz's witness suggests that if a university education provides one half of the moral measure for assessing the health of society, then the other half of this measure is found in the degree to which students entering these various worlds of social, political, and moral responsibility after college are able to exercise their accumulated practice and apply it in publicly redeeming ways. But how and in what manner such values are honed, refined, scrutinized, enacted, and studied in the public domain depends on the circumstances and persons according to which such ideas were rehearsed-prior to being staged and performed.

Paz discusses social change (Barnes does, too) when he delineates the social, political, and moral differences distinguishing life and thought between Mexico and the United States. As he sees it, "the causes that originate and the ideas that inspire these upheavals make them different from those that agitate our own countries, and therefore we would be committing a new error if we attempted to imitate them blindly" (Paz 1985, 219). While this statement is doubtless a reference to the history of positivism and its aftermath in Mexico, Paz's assertion that "it would be not be an error to take note of the capacity for criticism and self-criticism that is unfolding within them" both encourages an exploration of his purported relevance to and intersections with existentialism and the philosophy of education given to us by Barnes. $^{2}$ After all, Paz clearly believes that "the capacity for criticism and self-

\footnotetext{
${ }^{1}$ The Partido Revolucionario Institucional, or PRI, was Mexico's dominant political party for 71 years whose putative dictatorship held a grip over all facets of social, political, and moral life in Mexico. The PRI recaptured the Mexican Presidency in 2012 with the election of Enrique Peña Nieto.

${ }^{2}$ See Leopoldo Zea's Positivism in Mexico for a broad account of educational ideals, policies, and goals in Mexico during the late nineteenth and early twentieth century. Perhaps one imagines that the tumultuous extremes of 1968 would have called for even more radical discussions about the mission of
} 
criticism," or what I earlier identified as the double sense of moral criticism Barnes offers (personal criticism of oneself and social-political criticism of institutions and others), is a capacity that "would be futile to search for in Latin America." The reason for this view according to Paz's thinking is that "we still have not learned how to think with true freedom. The fault is not intellectual but moral" (Paz 1972, 219).

Historians of the period ignore the universal significance of Tlatelolco and the Mexican social protest movement of 1968. Robert Daniels, for instance, claims that "there was a striking common denominator to the upheavals of 1968, wherever they erupted...the target of rebellion was power-power over people and power over nations, power exercised on the international plane by great imperial states, by governments within nations, or by people in positions of dominance over the powerless under them, from the industrial bureaucracy to the university classroom" (Daniels 1989, 5). And yet, Daniels makes no mention of Tlatelolco, a fact eerily consistent with the circumstances of the time. "No newspaper in Mexico dared to print the number of deaths," writes Paz, adding that "Here is the figure that the English newspaper The Guardian, after a careful investigation, considered the most probable: 325. Thousands must have been injured, thousands must have been arrested. The second of October, 1968, put an end to the student movement. It also ended an epoch in the history of Mexico" (Paz 1985, 235.) Paz's view is clearly conservative. In his essay '68, Paco Ignacio Taibo II writes,

Over time, regrettably the second of October, with the tremendous power of our four hundred dead, many of them nameless corpses tossed from military airplanes into the Gulf of Mexico that same night, with the images of the wounded being dragged off by their hair, captured for posterity by the camera, with the memory of blood on the wet ground, with our retinas invaded and forever marked by the light of the two flares that started the massacre, with the stories of hospitals assailed by judicial-police officials intent on finishing off the wounded - regrettably, that day has been isolated (Taibo 2004, 108).

Thus one of the most damaging legacies any attempt at relating North American and Latin American philosophies of education to a pan-American model faces is the problem of obscurity, of forgotten memory.

the liberal arts university than those provided by Barnes and Paz. In response to such criticism, we might ask: has the public need for an education based in ethics changed significantly for the generations that have emerged in the United States and Mexico since the late 1960s? No. I do not believe the normative expectations for the university educated has changed considerably since then; nor do I think that raising questions about the moral mission of the university is any less vital today than it was half a century ago. As evidence for what one might despairingly deem the everlasting crisis of education, even a cursory glance at the range of recent works dealing with the crisis of the modern university suggests that the relation between our personal system of values on the one hand, and the role that institutions can and should play in furthering our social and political values on the other, calls for not just reexamination but considerable reform. Education-including but certainly not limited to its parameters, relevance, cost, and, above all, its purpose - continues to be passionately and publicly contested. 
That Barnes and Paz offer original insights into the relationship between the mission of the university and the necessity of moral criticism can be seen by placing their contributions next to today's more familiar Latin American exemplar in the philosophy of education. Paolo Freire's Pedagogy of the Oppressed was published in Portuguese in 1968, the same year as the student butchery at Tlatelolco. ${ }^{3}$ Freire's work was translated into English in 1970, the same year that Barnes' The University as the New Church came into print. Freire's philosophy of education resonates deeply with Barnes and Paz. This is particularly evident in his focus on the dynamic processes involved in problem-posing as opposed to the banking-deposit view of education, and it is likewise evident in his declared need to emphasize the value of love across student-teacher relations.

In conclusion, I want to elaborate on what I have argued is the threefold relationship (pyramid) of their affinity; viz., the centrality of values to a university education; the development of moral criticism through exposure to these values during one's university education; and the relevance and importance of moral criticism (seen both as the paradox of distance and as an art of living) to all human beings. Stretched in a manner that recalls and reinvigorates the engaged social ideal of what Simone de Beauvoir called surpassing, or the moral dynamism that characterizes individual human beings acting towards an open and not a closed or predetermined future, these resemblances can be seen as guidelines or distance markers for protecting and promoting the conditions under which students learn how to think through and act upon the issues (values) that define one's identity and place, socio-political relations, and lived experience.

To return to the first guideline, Barnes and Paz maintain that any meaningful university education should be evaluated in terms of curriculum as well as lived experience. What students are taught and how they grow to think about what they have studied are equal tasks at the university level. Their view thus implies that a genuine education should be focused on the radical allowance or opening-up of moral practice, e.g., thinking through solutions to real world problems. Barnes invokes the phrase "open breathing space" to describe her wish that individuals have the room to work out their "personally created system of values" (Barnes 1970, 34). What their focus on values as the core of a university education shows is that student activism helps ensure the rehearsal of values so integral to the mission of the liberal arts university and hence so vital to a meaningful experience of higher learning.

Second, the task of envisioning a future where moral criticism becomes the lifeblood of economic geographies and political communities reveals one practical application of the existentialist philosophies of education provided by Barnes and Paz. Granting that their ideas about what an education amounts to were an obvious starting point for them as each sought to locate the origins, pinpoint the aims, and discuss the values underlying moral criticism, their concerns were also focused on how values translate from individual persons to social bodies, and from the body politic back, once again, to selves in action. Their sense of moral dynamism across 
generations might therefore be seen as the normative underpinning of the university mission in terms not only of cultivating a sense, on the personal level, of the importance of thinking through and having values, but of knowing how to put those values to use in terms of articulating and expressing moral criticism. It follows from this fluidity of identity that their educational views therefore also raise implications for an existentialist account of political socialization.

Finally, that moral criticism of one's own social and political realities is always checked, so to speak, by how we see our individual selves in terms of the actions we undertake as members of the same generation helps to prepare us for the inevitable conflict that characterizes difference within as well as between bodies, social groups, communities, and nations. What Barnes and Paz were attempting to accomplish through their purported philosophies of education was, I think, to make better sense of the challenges facing the emerging generation of social-political actors, artists, and democratic visionaries in order to encourage such reforms towards reinvigorated, more cohesive democratic institutions and practices. As Paz tells us in his characterization of the irresolvable contradiction of the university: "If the university were to disappear, so would the possibility of criticism; at the same time, its existence is a proof - and more, a guarantee — of the permanence of the object of criticism, that is, of what it wished would disappear" (Paz 1972, 223). In speaking to the production of an existentialist pan-American philosophy of education in the work of Barnes and Paz, then, it seems appropriate to say that the stage curtain remains open to the seasonal and generational audiences of students, teachers, and other social actors who attend the show only to find themselves already deeply a part of the production underway.

\section{ACKNOWLEDGEMENTS}

The author would like to thank the anonymous reviewers for Comparative Philosophy who offered insightful and helpful comments. Special thanks is also owed to University Archivist Barbara Floyd at the University of Toledo Archives who helped locate several Barnes documents, including the cited college newspaper editorial by Barnes. The author also thanks Lara de Bruijn for her companionship and support.

\section{REFERENCES}

Barnes, Hazel (1997), The Story I Tell Myself: A Venture in Existentialist Autobiography (Chicago: University of Chicago Press).

- (1978), An Existentialist Ethics (Chicago: University of Chicago Press).

- (1970), The University as the New Church (London: C.A. Watts and Co).

- (1959), Humanistic Existentialism: The Literature of Possibility (Lincoln: University of Nebraska Press). 
- (March 1950), Op-ed piece in Collegian. University of Toledo Archives, Toledo, $\mathrm{OH}$.

Cannon, Betty (2008), "Hazel E. Barnes 1915-2008: A Tribute and Farewell." Sartre Studies International, 14 (2): 90-103.

Cohen-Solal, Annie (1989), Jean-Paul Sartre: A Life, intro. Cornel West, trans. Anna Cancogni (New York: New Press).

Daniels, Robert V. (1989), Year of the Heroic Guerilla: World Revolution and Counterrevolution in 1968 (Cambridge: Harvard University Press).

Freire, Paolo (2000), The Pedagogy of the Oppressed (New York: Bloomsbury Academic).

James, William (1958), Talks to Teachers On Psychology: And to Students on Some of Life's Ideals (New York: Norton).

Kaiser Ortiz, John (2012), "Octavio Paz and the Universal Problem of Mexican Solitude," American Philosophical Association Newsletter on Hispanic/Latino Issues, 11 (2), 1-5.

Krauze, Enrique (1998), "In Memory of Octavio Paz (1914-1998)", New York Review of Books: <http://www.nybooks.com/articles/archives/1998/may/28/in-memoryof-octavio-paz-19141998/>.

Paz, Octavio (1985). "The Other Mexico," in The Labyrinth of Solitude and Other Writings, trans. Lysander Kemp (New York: Grove Press).

- (1992). On Poets and Others, trans. Michael Schmidt (New York: Paladin).

Taibo II, Paco Ignacio (2004), '68, trans. Donald Nicholson-Smith. (New York: Seven Stories Press).

Zea, Leopoldo (1974), Positivism in Mexico, trans. Josephine H. Schulte (Austin: University of Texas Press). 